\title{
Research on the Influencing Factors of Service Group-buying Enterprise Marketing Competitiveness Based on Online Rating
}

\author{
Sa Zhou ${ }^{1, a}$, Yang Zhang ${ }^{1, b}$ and Yongjun Liü ${ }^{1, c}$ \\ ${ }^{1}$ School of Management, Wuhan University of Technology, Wuhan 430000, China. \\ azhsa1992@163.com, b924812422@qq.com, 'liuyongjun_163@163.com
}

\begin{abstract}
Keywords: online rating; group-buying enterprise; marketing competitiveness; multiple linear regression.
\end{abstract}

\begin{abstract}
This article studies the influencing factors of service group-buying enterprise marketing competitiveness based on the online rating. Firstly, on the basis of existing research results about the marketing competitiveness of group-buying enterprise and the features of service group-buying enterprise, the article analyzes the inscape of service marketing competitiveness of group-buying enterprise. Secondly, the article proposes hypotheses about service group-buying enterprise marketing competitiveness from seven aspects: the overall emotional polarity rating, the price rating, the service quality rating, the refund rating, the services quality of off-line businesses rating, the number of businesses rating, the reputation of service group-buying enterprise, and then builds multiple linear regression model. Finally, the article applies SPSS software to solve and analyze the established model, and reveals the significance of each influencing factor and verifies the original hypotheses, which points out how these factors influence the marketing competitiveness of service group-buying enterprise. The article has some certain guidance for the service group-buying enterprise to develop their marketing strategies.
\end{abstract}

\section{Introduction}

In 2008, online group-buying website Groupon had achieved great success in the U.S, and then its business model quickly spread on around the world. As an important pattern of online buying, group-buying develops quite rapidly in China. Group-buying benefits both customers and group-buying enterprises. Customers will get high-quality, affordable products or services, group-buying enterprises will gain more popularity and expand their market share.

With the development of Internet technology, customers have changed their way to get sales information. They no longer ask their friends to make purchase decisions but look for user generated content (UGC) on the Internet. A global survey in 2011 showed that ninety percent of customers were accustomed to browse product review information before buying [1]. And it was also found in 2013 eMarketer survey that compared with expert opinion customers were more inclined to believe those unfamiliar consumers who had bought same product [2]. Therefore, online review information has become an important reference for customers to make purchase decisions.

Online review information (especially online rating) has a significant impact on the marketing competitiveness of group-buying enterprise, so more and more group-buying websites provide platform for their customers to publish online reviews. Many scholars have studied the effects of online rating on online buying enterprise. Amblee and Bui (2008) found that $26 \%$ of the Internet users had written online reviews and $61 \%$ of the online customers thought online reviews were valuable and reliable [3]. Shen (2012) believed that negative and subjective online reviews had a greater influence on customers' decision-making than other reviews [4]. Reinstein and Snyder (2005) argued that the level of online rating was correlated with the product sales, which meant that low online rating would reduce the product sales [5]. Similarly, Chevalier and Mayzlin (2006) discovered that online rating played an important role in the online book sales, and customers liked to buy those books with high score reviews [6]. But there are many problems in the current group-buying, such as refund issues, 
poor services, poor product quality and dissatisfying with after-sales service, which can be reflected in online rating [7]. The above problems make it harder for group-buying enterprises to improve their marketing competitiveness. Thus, group-buying enterprises need to understand how those online rating information influence their marketing competitiveness.

\section{Theoretical Development: Marketing Competitiveness of Service Group-buying Enterprise}

Characteristics of Service Group-buying. The definition of service group-buying is that customers who share same purchase intention and are gathered together by Internet buy the same product or service with a same discount. Compared with other mode of group-buying, service group-buying provides serving product which is virtual and have a low dependence on logistics. And when participating in service group-buying, customers should make payment to group-buying website directly before they receive the product or enjoy the service, rather than paying through the third-party payment platform. So this will make the information asymmetric between customers and group-buying enterprise, which will result in the increasing rates of complaints. Furthermore, the consumer groups of service group-buying are young people so that the service group-buying website is more active than other group-buying website and will produce large amounts of online rating information.

Analysis of Marketing Competitiveness of Service Group-buying Enterprise Based on Online Rating. The marketing competitiveness of enterprise is an ability to gain an advantage in market competition and create customer value by developing marketing strategies and making marketing efforts, which includes five aspects: the ability of product innovation and development, the ability of quality control, the ability of brand management and marketing communication, the ability of supply chain and sales management and the ability of customer relationship management. And from consumers' perspective, the marketing competitiveness of group-buying enterprise is outwardly manifested as its site visits. High visits usually mean strong marketing competitiveness. So it is meaningful to regard customer visits as a measurement of the marketing competitiveness of group-buying enterprise.

The research of this article is aimed at service group-buying enterprise, which provides virtual product and is not related to logistics. Therefore, the research will extract influencing factors of marketing competitiveness of service group-buying enterprise from four dimensions: the ability of product innovation and development, the ability of quality control, the ability of brand management and marketing communication and the ability of customer relationship management. The ability of product innovation and development is reflected as the number of businesses in group-buying website, the ability of quality control is reflected as service quality of businesses in group-buying website, the ability of brand management and marketing communication is reflected as the reputation of service group-buying enterprise, and the ability of customer relationship management manifests through service quality of group-buying website and treatment of refund issue. In addition, according to consumer purchase decision theory and online rating effect, the influencing factors of marketing competitiveness of service group-buying enterprise also include the price of products and overall emotional polarity rating.

\section{Hypotheses Development}

Emotional Polarity of Online Rating. The emotional polarity of online rating refers to the customer's attitude towards product, which shows customer's love or hate attitude after using product or enjoying service. Many potential customers will hold the same emotional attitude after they view those online comments, which have an impact on their purchase decision. This phenomenon is also called persuading effect.

In the study of this issue, Ye et al. (2009) selected hotel reservation as research object and found that the booking number increased as the mean score of online rating increased [8]. Hao (2010) argued that extreme poor rating and extreme high rating had a most significant impact on movie box 
office in a study of online film critic data [9]. The overall emotional polarity rating is the numeric rating that is given by customer which is an important part of online rating.

H1: The overall emotional polarity rating has a significant impact on customer visits of group-buying enterprise.

Relationship between Product Price and Online Consumer Demand. According to the law of value in economics and marketing management, the price of product has a negative correlation with the customer demand. Kotler (2011) pointed out that the lower the price, the more the tendency of consumers to make purchase decisions [10]. Similarly, during the online shopping, consumer's buying behavior closely relates to the product price.

H2: The price rating of group-buying enterprise which is given by customers has a significant positive impact on customer visits.

Service Quality Rating of Group-buying Website. Kim et al. (2008) believed that high level of website service and considerate customer care would undoubtedly affect customer satisfaction [11]. Xie et al. (2011) argued that the ability to communication with customer and the ability to handle customer's needs directly reflected the service capability and quality of website [12]. Thus, to provide good help and complaint service for customer is an important way for group-buying enterprise to survive and develop.

H3: The service quality rating of group-buying enterprise has a significant positive impact on customer visits.

After-sales Service of Group-buying. In a survey at the causes of complaints to group-buying site found that most people chose "refund issue" as the reason why they complained. The proportion reached $43.18 \%$, which was the highest among all reasons of complaint [13]. Refund issue usually includes refunding not in time, strict conditions of refunding and so on. The refund rating (numeric rating about refund service which is a component of online rating) will affect other consumer visits.

H4: The refund rating of group-buying enterprise has a significant positive impact on customer visits.

Service Quality of Off-line Businesses. The service quality and customer satisfaction is an important part in service management. It has been proved that customer satisfaction is most directly affected by business's service quality and service quality is the antecedent variable of customer satisfaction. Cronin and Taylor (1992) believed that by influencing customer satisfaction, service quality could play an important role in influencing customer purchase intention [14]. Wang et al. (2003) considered that customer satisfaction was more easily influenced by intangible quality of service and was an important factor in deciding whether to visit next time [15]. Most off-line businesses in service group-buying website provide intangible service, and good off-line service always leads to higher customer visits.

H5: The service quality of off-line businesses rating has a significant positive impact on customer visits.

Number of Businesses in Group-buying Website. Richness of commodities is of great importance for online group-buying. For group-buying enterprise, the number and types of businesses in group-buying website have great impacts on customer visits. A large number of businesses in group-buying website usually bring more customer visits.

H6: The number of businesses rating has a significant positive impact on customer visits.

Reputation of Group-buying Enterprise. Reputation is an important signal for group-buying website to convey their reliability, which will make customer trust the information on the website and effectively reduce the risks in purchasing process. And enterprises will use their reputation to attract customers to buy their products. And while researching the reputation of scientists, Bagrow and Hernan (2004) used Google to search related names and regarded the number of search results as the measurement of the reputation of scientists [16]. Referring to this method, this article will use Baidu Index of group-buying enterprise as the measurement of the reputation of group-buying enterprise.

H7: The reputation of group-buying enterprise has a significant positive impact on customer visits. 


\section{Model Development and Data Collection}

According to the above hypotheses, this article establishes multiple linear regression equation, which takes seven influencing factors as independent variable and the customer visits of group-buying enterprise as dependent variable. Because of the data of customer visits and the Baidu Index of group-buying enterprise (the measurement of reputation) have a big order of magnitude, using logarithm of the variable PageView $i$ and variable Reputation $i$ will make the distribution of the original variables become more smoother. And the article establishes the model as follows.

$$
\begin{aligned}
\text { PageView }_{i}(\log )= & \alpha+\beta_{1} * \text { TotalRate }_{i}+\beta_{2} * \text { PriceRate }_{i}+\beta_{3} * \text { ServiceRate }_{i}+\beta_{4} * \text { RefundRate }_{i} \\
& +\beta_{5} * \text { OffServiceRate }_{i}+\beta_{6} * \text { BussNumRate }_{i}+\beta_{7} * \text { Reputation }_{i}(\text { Log })+\zeta_{i}
\end{aligned}
$$

The meaning of each variable in the model is shown in the following table.

\begin{tabular}{|c|c|}
\hline variable & meaning \\
\hline$\overline{\mathrm{i}}$ & The ith group-buying enterprise. \\
\hline PageView $_{\mathrm{i}}$ & $\begin{array}{l}\text { The customer visits of the ith group-buying enterprise,the data is from the } \\
\text { records in Alexa site. }\end{array}$ \\
\hline TotalRate $_{i}$ & The overall emotional polarity rating of the ith group-buying enterprise. \\
\hline PriceRate $_{i}$ & The price rating of the ith group-buying enterprise. \\
\hline ServiceRate $_{i}$ & The service quality rating of the ith group-buying enterprise. \\
\hline RefundRate $_{i}$ & The refund rating of the ith group-buying enterprise. \\
\hline OffServiceRate $_{i}$ & $\begin{array}{l}\text { The services quality of off-line businesses rating of the ith group-buying } \\
\text { enterprise. }\end{array}$ \\
\hline BussNumRate $_{i}$ & The number of businesses rating of the ith group-buying enterprise. \\
\hline Reputation $_{\mathrm{i}}$ & $\begin{array}{l}\text { The reputation of the ith group-buying enterprise, the data is from Baidu } \\
\text { Index. }\end{array}$ \\
\hline
\end{tabular}

Table 1 The meaning of each variable in the model

This article uses a web data extractor to collect a total of 3162 records about online rating from Baidu Koubei website which is the biggest UGC aggregation platform in China, and then divides them into 22 groups by group-buying enterprise name, so a total of 22 enterprises are studied. In each record, each rating is processed into Likert five-point scale representation. One point indicates that customer has a very poor evaluation; while five points indicates that customer has a very good evaluation. And as for the number of businesses in group-buying enterprise, it comes from the data that is collected by manually finding. In the 22 groups of collected data, by taking arithmetic mean value of each type of rating, we will get the overall emotional polarity rating, the price rating, the service quality rating, refund rating and the services quality of off-line businesses rating of each group-buying enterprise. The reputation data of group-buying enterprise is collected from Baidu Index site (www.index.baidu.com) and measured by average monthly search index. Finally, the customer visits data of group-buying website is gathered from Alexa site (www.alexa.cn) which is the leading company to provide website traffic statistics on the Internet. And this article selects the most representative data-average daily IP as the measurement of customer visits.

\section{Result and Model Checking}

Based on the processed data, the article uses SPSS software to solve and analyze the model. Results of coefficient estimation are as follows. 
Table 2 Result of coefficient estimation

\begin{tabular}{|c|c|c|c|c|c|c|c|}
\hline \multirow{2}{*}{ Model } & \multicolumn{2}{|c|}{$\begin{array}{c}\text { Unstandardized } \\
\text { Coefficients }\end{array}$} & $\begin{array}{c}\text { Standardized } \\
\text { Coefficients }\end{array}$ & \multirow{2}{*}{$\mathrm{t}$} & \multirow{2}{*}{ Sig. } & \multicolumn{2}{|c|}{$\begin{array}{c}\text { Collinearity } \\
\text { Statistics }\end{array}$} \\
\cline { 2 - 5 } \cline { 6 - 8 } & $\mathrm{B}$ & Std. & & & & & \\
& tolerance & VIF \\
\hline (constant) & -5.330 & 1.094 & & -4.874 & .129 & & \\
\hline TotalRate & .774 & .720 & .243 & 1.340 & .039 & .201 & 4.964 \\
\hline PriceRate & -.197 & .204 & -.060 & -.967 & .511 & .387 & 2.584 \\
\hline ServiceRate & .030 & 1.321 & .219 & 1.730 & .034 & .392 & 2.553 \\
\hline RefundRate & .529 & .175 & .211 & 3.030 & .033 & .304 & 3.291 \\
\hline OffServiceRate & 1.241 & .582 & .564 & 2.992 & .005 & .341 & 2.929 \\
\hline BussNumRate & .740 & .499 & .988 & 1.705 & .001 & .665 & 1.493 \\
\hline Reputation & .921 & .072 & .637 & 4.954 & .044 & .360 & 2.780 \\
\hline
\end{tabular}

The significance test of whole model shows in Table 3. From the Tables 3 it is known that the F-test of the whole model is at the value of 96.878 and the significance value is 0.00 , which indicates that the whole model is significant.

Table 3 F-test of whole model

\begin{tabular}{cccccc}
\hline Model & Sum of Squares & df & Mean Square & F & Sig \\
\hline Regression & 86.869 & 7 & 10.759 & 96.878 & .000 \\
Residual & 79.004 & 94 & .872 & & \\
Total & 165.873 & 103 & 11.631 & & \\
\hline
\end{tabular}

The results of test of goodness of fit show in Table 4 . The value of adjusted R-square is 0.548 , which proves that the whole model have a high fitting degree. As can be seen from the above test, the multivariate linear regression model that is established in this study is valid and can explain the dependent variable at a high level.

Table 4 Summary of fit

\begin{tabular}{ccccc}
\hline Model & $\mathrm{R}$ & $\mathrm{R}^{2}$ & Adjusted $\mathrm{R}^{2}$ & Std. \\
\hline 1 & .769 & .569 & .548 & .54845340 \\
\hline
\end{tabular}

From the results in Table 2, the significant value of PriceRate variable is 0.511 , which exceeds 0.05, so the second hypothesis is not supported. And the significant value of ServiceRate variable is 0.034 but the partial regression coefficient value is 0.030 , so the third hypothesis is partially supported. Supporting for other hypotheses shows in Table 5.

Table 5 Supporting for the hypotheses

\begin{tabular}{c|c}
\hline Hypotheses & Whether to support \\
\hline H1 & Supported \\
\hline H2 & Not supported \\
\hline H3 & Partially supported \\
\hline H4 & Supported \\
\hline H5 & Supported \\
\hline H6 & Supported \\
\hline H7 & Supported \\
\hline
\end{tabular}

\section{Conclusion}

Through the multivariate linear regression analysis on the influencing factors of service group-buying enterprise marketing competitiveness, it is known that the overall emotional polarity rating, the refund rating, the services quality of off-line businesses rating, the number of businesses rating and the reputation have a significant positive effect on customer visits. In other words, these factors play crucial roles in promoting the marketing competitiveness of service group-buying enterprise. And the extent of influence of these factors in order to sort as follows: services quality of 
off-line businesses, reputation of group-buying enterprise, overall emotional polarity, number of businesses in group-buying website and refunding.

However, the price rating has no significant effect on the marketing competitiveness of service group-buying enterprise. Maybe it's because the group-buying enterprise is known for its low prices and the price of product (or service) in the website is within the acceptable range for the customer. Customer will not concern the price rating while browsing the online rating information. And the service quality rating of group-buying enterprise has a positive effect on the marketing competitiveness of service group-buying enterprise, but the correlation is not significant. This could be due to the fact that the customer only needs to contact with the off-line businesses in the group-buying website instead of group-buying enterprise itself which make the customer not particularly demand on the service quality of group-buying enterprise.

In a word, this article has established the model of influencing factors of service group-buying enterprise marketing competitiveness based on online rating, and by demonstration and analysis, pointed that how these factors affect the marketing competitiveness of service group-buying enterprise. The research can provide a certain reference for the management and development of service group-buying enterprise, especially for the improvement of marketing strategy.

\section{References}

[1] Information on http://go.channeladvisor.com

[2] Information on http://www.emarketer.com

[3] Amblee N, Bui T, Can brand reputation improve the odds of being reviewed on- line, International Journal of Electronic Commerce, 12(2008) 11-28.

[4] F. Shen, An empirical research on the purchase behaviour of online group-buying product based on word of mouth, Consumer Economics, 2(2012) 49-52 (In Chinese).

[5] D. Reinstein, C. M, Snyder, The influence of expert reviews on consumer demand for experience goods:a case study of movie critics, Journal of Industrial Economics, 53(2005) 27-51.

[6] Chevalier J A, Mayzlin D, The effect of word of mouth on sales:online book reviews, Journal of Marketing Research, 43(2006) 345-354.

[7] Information on http://www.100ec.cn

[8] Ye Q, Law R, Gu B, The impact of online user reviews on hotel room sales, International Journal of Hospitality Management, 28(2009) 180-182.

[9] Y.Y. Hao, An empirical research about the impact of user online reviews on consumer perception and purchase behaviors, Ph.D., Harbin Institute of Technology, China 2010 (In Chinese).

[10] Philip Kotler, Marketing Management, 14th ed., Prentice Hall, Upper Saddle River,NJ 2011.

[11] Minho Kim, Han Mo Oh, Ronald D. Mc Niel, Determinants of online shoppers satisfaction in Korea, Applied Economics Letters, 15(2008) 805-808.

[12] P.H. Xie, H.M. Xi, N.J. Wei, X. Liu, An empirical study on the influcing factors of customer satisfaction in B2C E-commerce in China, Science Research Management, 10(2011) 109-117 (In Chinese).

[13] Information on http://www.cnit-research.com

[14] Cronin Jr. J. J., Taylor S.A., Measuring service quality:a reexamination and extension, The Journal of Marketing, 56(1992) 55-68.

[15] C.X. Wang, X.Y. Han, B.Y. Wen, An empirical study on the relationship between customer satisfaction and loyalty, Nankai Business Review, 6(2003) 70-74 (In Chinese).

[16] James P. Bagrow, Hernan D., How Famous is a Scientist?--Famous to Those Who Know Us, Europhysics Letters, 67(2004) 511-516. 